\title{
PENGARUH MOTIVASI, PERSEPSI RISIKO DAN PENGETAHUAN INVESTASI TERHADAP MINAT BERINVESTASI DI MASA PANDEMI COVID-19
}

\author{
Darson Widia Atmaja dan Sawidji Widoatmodjo \\ Fakultas Ekonomi dan Bisnis, Universitas Tarumanagara, Jakarta \\ Email: \\ darson.115170239@stu.untar.ac.id \\ sawidjiw@pps.untar.ac.id
}

\begin{abstract}
Abstrak: Penelitian ini menguji pengaruh motivasi, persepsi risiko, dan pengetahuan investasi terhadap minat berinvestasi di masa pandemi Covid-19. Jumlah sampel yang digunakan dalam penelitian ini adalah 200 sampel yang dipilih menggunakan metode purposive sampling dan diperoleh menggunakan kuesioner. Pengolahan data menggunakan bantuan aplikasi SmartPLS. Hasil penelitian menunjukkan bahwa motivasi dan pengetahuan investasi berpengaruh positif terhadap minat berinvestasi di masa pandemi Covid-19, sedangkan persepsi risiko tidak signifikan berpengaruh terhadap minat berinvestasi di masa pandemi Covid-19.
\end{abstract}

Kata Kunci : Motivasi, Persepsi Risiko, Pengetahuan Investasi, Minat Berinvestasi, Covid-19

Abstract : This study examines the effect of motivation, risk perception, and investment knowledge on investment interest during the Covid-19 pandemic. The number of samples used in this study was 200 samples selected using the purposive sampling method and obtained using a questionnaire. Data processing using SmartPLS application assistance. The results showed that investment motivation and investment knowledge had a positive effect on interest in investing during the Covid-19 pandemic, while risk perception did not significant.

Keywords : Motivation, Risk Perception, Investment Knowledge, Investment Intention, Covid19

\section{LATAR BELAKANG}

Terjadinya pandemi Covid-19 membuat teknologi informasi semakin banyak digunakan sehingga semakin banyak Platform Digital bermunculan yang memberikan kemudahan kepada masyarakat luas untuk berbelanja secara online. Salah satunya adalah memberikan kemudahan bagi masyarakat untuk memilih cara untuk berinvestasi bahkan juga dapat mengedukasi para penggunanya mengenai pengetahuan investasi dasar serta pasar modal. Pasar modal adalah tempat untuk mentransaksikan modal jangka panjang dimana permintaan diwakili oleh perusahaan penerbit surat berharga dan penawaran diwakili oleh para investor (Widoatmodjo, 2009)

Berdasarkan data statistik pertumbuhan investor (Single Investor Identification) (PT. Kustodian Sentral Efek Indonesia, 2020) mengatakan sepanjang tahun 2020 terdapat peningkatan sebesar 55,83\% investor pasar modal apabila dibandingkan dengan akhir tahun 2019. Peningkatan tersebut dapat dikatakan cukup besar apabila dibandingkan dengan tahuntahun sebelumnya.

Meskipun demikian, masih ada yang belum berminat berinvestasi karena masih ada anggapan bahwa investasi memiliki risiko yang cukup besar, dan juga kurangnya motivasi bagi mereka untuk berinvestasi di pasar modal. maka dari itu, program edukasi mengenai investasi 
sangat diperlukan dengan bekerja sama kepada institusi pendidikan dengan tujuan masyarakat terlebihnya mahasiswa dapat lebih memahami pentingnya investasi pada masa sekarang.

(Rezeki dan Pitaloka, 2020) mengatakan beberapa faktor yang mempengaruhi keputusan investasi yaitu pengetahuan pasar modal, fluktuasi harga saham selama pandemi dan juga risiko yang dihadapi saat akan melakukan investasi. Berdasarkan hal tersebut, maka peneliti tertarik untuk melakukan penelitian ini.

\section{KAJIAN TEORI}

Teori yang digunakan dalam penelitian ini adalah The Theory of Planned Behavior (Teori Perilaku Terencana) yang merupakan pengembangan dari The Theory of Reasoned Action (Teori Perilaku Beralasan) yang mengatakan bahwa faktor sentral dari perilaku individu adalah bahwa perilaku individu itu dipengaruhi oleh niat individu terhadap perilaku tertentu tersebut (Ajzen, 1991).Teori ini membahas tiga penentu niat yang independen dan secara konseptual yaitu Attitudes (Sikap) yang mengacu pada sejauh mana seseorang memiliki evaluasi atau penilaian yang disukai maupun tidak disukai dari perilaku yang bersangkutan, kemudian Subjective Norms (Norma Subjektif) yang mengacu pada tekanan sosial yang dirasakan untuk melakukan ataupun tidak melakukan sesuatu dan Perceived Behavioral Control (Persepsi Kontrol Kepribadian) yang membahas tentang perasaan seseorang mengenai mudah atau sulitnya untuk mewujudkan suatu perilaku tertentu.

Motivasi didefinisikan sebagai sebuah proses yang memperhitungkan intensitas, arah serta usaha individu untuk mencapai tujuannya masing-masing (Robbins, 2006). Persepsi Risiko merupakan kondisi yang diperlukan untuk mempertimbangkan risiko dalam kategori penentu keputusan pembelian (Maciejewski, 2011).

Investasi adalah aset apa pun yang dapat digunakan oleh investor untuk meletakkan dananya dengan harapan dapat mendapatkan penghasilan positif ataupun meningkatkan nilai uang tersebut. (Haugen dan Branch, 1977). Minat berinvestasi diasumsikan dapat menangkap faktor-faktor motivasi yang mempengaruhi tingkah laku atau perilaku seseorang. Tingkah laku atau perilaku yang dimaksud adalah untuk melakukan investasi (Ajzen, 1991).

Pengambilan keputusan atas suatu tindakan tentu dipengaruhi oleh banyak hal, tidak terkecuali di dalam investasi seperti Pengetahuan Investasi, Motivasi Investasi hingga Persepsi terhadap Risiko atas suatu keputusan Investasi. Pengetahuan Dasar atas investasi yang harus diketahui oleh investor maupun calon investor sebelum mengambil keputusan investasi adalah mengukur seberapa besar return atau imbal hasil yang akan diperoleh atas produk yang telah dipilih. Para investor akan cenderung memilih investasi dengan tingkat return yang tinggi, namun pada umumnya return yang tinggi diiringi dengan tingkat risiko yang tinggi juga. Maka dari itu Pengetahuan Investasi diperlukan untuk dapat mengambil keputusan investasi yang tepat untuk masing-masing investor.

Tingkat return yang tinggi dapat menjadi dorongan bagi investor untuk melakukan investasi meskipun risiko yang dihadapi juga besar, hal ini dapat memotivasi investor dengan kategori Risk Seeker, beda halnya pada investor dengan kategori Risk Averter yang cenderung memilih untuk menghindari risiko sehingga mereka lebih memercayakan dananya pada instrumen investasi dengan risiko yang minim. Motivasi investasi muncul karena seseorang telah memenuhi kebutuhan substansialnya, dan ingin memenuhi kebutuhan di atasnya seperti kebutuhan akan aktualisasi diri. Kerangka pemikiran pada penelitian ini akan diuraikan sebagai berikut : 


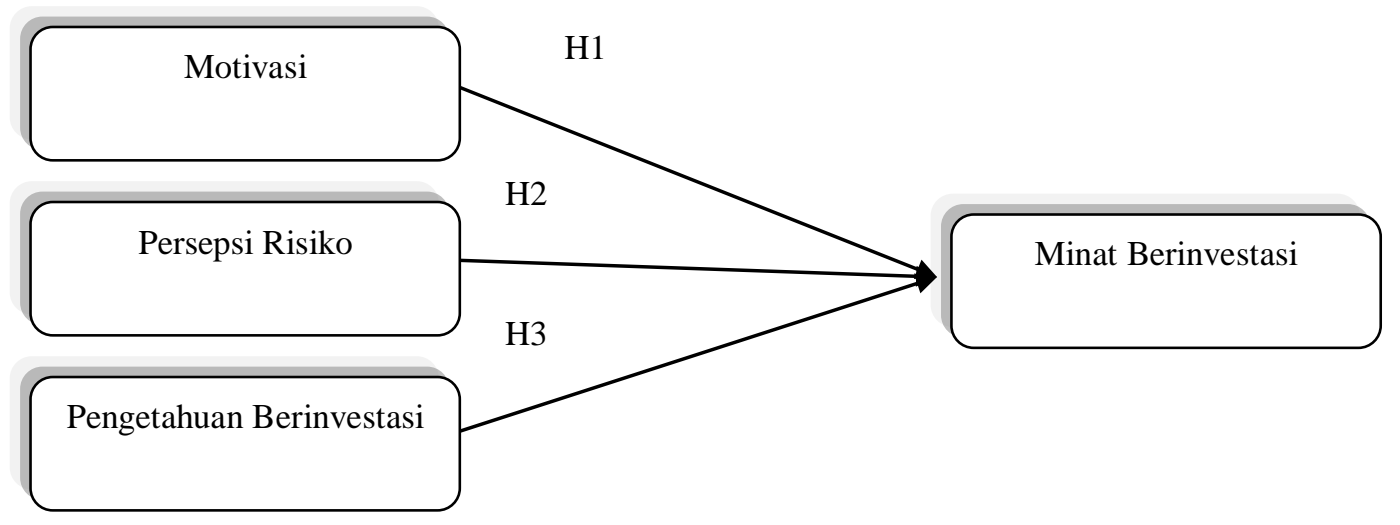

Gambar 1. Kerangka Pemikiran

Berdasarkan Kerangka Pemikiran di atas, maka hipotesis yang akan diuji adalah sebagai berikut :

H1 : Motivasi berpengaruh positif terhadap Minat Berinvestasi.

$\mathrm{H} 2$ : Persepsi Risiko berpengaruh positif terhadap Minat Berinvestasi.

$\mathrm{H} 3$ : Pengetahuan Investasi berpengaruh positif terhadap Minat Berinvestasi.

\section{METODOLOGI}

Desain penelitian yang digunakan dalam penelitian ini adalah desain penelitian deskriptif menggunakan metode kuantitatif. Aritonang (1998) menjelaskan tujuan dari penelitian deskriptif adalah untuk menguji kebenaran hipotesis dari keterkaitan antar variabel. Subjek penelitian pada penelitian ini adalah mahasiswa FEB Universitas Tarumanagara. Teknik pengambilan sampel yang digunakan adalah Purposive Sampling dengan kriteria responden yang mengetahui tentang Investasi. Objek penelitian Minat Berinvestasi sebagai variabel dependen, Motivasi, Persepsi Risiko dan Pengetahuan Investasi sebagai variabel Independen. Tingkat signifikansi yang digunakan dalam penelitian ini sebesar 5\%. Data dikumpulkan menggunakan bantuan Google-form yang kemudian diolah dan dianalisis dengan statistik deskriptif, analisis Inner Model yang terdiri dari Uji Koefisien Determinasi, Predictive Relevance. Path Coefficients, dan Effect Size, Uji Goodness of Fit dan terakhir Uji Hipotesis menggunakan SmartPLS.

\section{HASIL ANALISIS DATA}

Analisis Statistik Deskriptif

Tabel 1 Hasil Analisis Statistik Deskriptif

\begin{tabular}{|c|c|c|c|c|c|}
\hline Indikator & Mean & Median & Minimum & Maksimum & $\begin{array}{c}\text { Deviasi } \\
\text { Standar }\end{array}$ \\
\hline MOT1 & 3.865 & 4 & 1 & 5 & 1.008 \\
\hline MOT2 & 3.965 & 4 & 1 & 5 & 0.845 \\
\hline MOT3 & 3.825 & 4 & 1 & 5 & 1.193 \\
\hline MOT4 & 4.13 & 4 & 1 & 5 & 0.976 \\
\hline MOT5 & 4.095 & 4 & 1 & 5 & 1.018 \\
\hline MOT6 & 4.125 & 4 & 1 & 5 & 0.974 \\
\hline MOT7 & 4.255 & 4 & 1 & 5 & 0.806 \\
\hline MOT8 & 4.135 & 4 & 1 & 5 & 1.003 \\
\hline
\end{tabular}




\begin{tabular}{|c|c|c|c|c|c|}
\hline MOT9 & 3.4 & 3 & 1 & 5 & 1.179 \\
\hline PERISK1 & 4.575 & 5 & 2 & 5 & 0.696 \\
\hline PERISK2 & 4.27 & 4 & 1 & 5 & 0.823 \\
\hline PERISK3 & 4.225 & 4 & 2 & 5 & 0.902 \\
\hline PERISK4 & 3.115 & 3 & 1 & 5 & 0.981 \\
\hline PERISK5 & 3.48 & 4 & 2 & 5 & 0.985 \\
\hline PERISK6 & 3.655 & 4 & 2 & 5 & 0.967 \\
\hline PERISK7 & 3.295 & 3 & 2 & 5 & 0.979 \\
\hline PERISK8 & 3.565 & 4 & 2 & 5 & 0.993 \\
\hline PERISK9 & 3.81 & 4 & 1 & 5 & 0.857 \\
\hline IKL1 & 4.855 & 5 & 2 & 5 & 0.417 \\
\hline IKL2 & 4.19 & 4 & 2 & 5 & 0.862 \\
\hline IKL3 & 4.64 & 5 & 2 & 5 & 0.609 \\
\hline IKL4 & 4.41 & 5 & 1 & 5 & 0.82 \\
\hline IKL5 & 4.39 & 5 & 2 & 5 & 0.706 \\
\hline IKL6 & 3.95 & 4 & 2 & 5 & 0.921 \\
\hline IKL7 & 4.31 & 4 & 1 & 5 & 0.821 \\
\hline IKL8 & 4.285 & 4 & 2 & 5 & 0.731 \\
\hline IKL9 & 3.995 & 4 & 2 & 5 & 0.919 \\
\hline INTENT1 & 3.905 & 4 & 2 & 5 & 0.834 \\
\hline INTENT2 & 3.18 & 3 & 2 & 5 & 1.043 \\
\hline INTENT3 & 3.985 & 4 & 1 & 5 & 0.851 \\
\hline INTENT4 & 3.325 & 3 & 1 & 5 & 1.208 \\
\hline INTENT5 & 3.89 & 4 & 1 & 5 & 0.953 \\
\hline INTENT6 & 4.085 & 4 & 2 & 5 & 0.899 \\
\hline INTENT7 & 3.99 & 4 & 1 & 5 & 0.99 \\
\hline INTENT8 & 4.395 & 5 & 2 & 5 & 0.713 \\
\hline INTENT9 & 4.095 & 4 & 2 & 5 & 0.84 \\
\hline INTENT10 & 3.905 & 4 & 2 & 5 & 0.898 \\
\hline INTENT11 & 4.245 & 4 & 1 & 5 & 0.851 \\
\hline
\end{tabular}

Sumber : Hasil pengolahan data menggunakan SmartPLS

Berdasarkan tabel 1, diperoleh hasil analisis statistik deskriptif terhadap keseluruhan variabel yang meliputi motivasi, persepsi risiko dan pengetahuan investasi dari 200 sampel yang telah diambil dan memenuhi kriteria peneliti. Kesimpulan pada tabel di atas adalah sebagai berikut :

Dari 200 sampel variabel motivasi, diperoleh nilai mean masing-masing indikator lebih besar daripada nilai Standar Deviasi, maka penyimpangan data yang terjadi rendah, sehingga penyebaran nilainya merata.

Pada 200 sampel variabel persepsi risiko, diperoleh nilai mean masing-masing indikator lebih besar daripada nilai Standar Deviasi, maka penyimpangan data yang terjadi rendah, sehingga penyebaran nilainya merata.

Kemudian 200 sampel variabel pengetahuan investasi, diperoleh nilai mean masingmasing indikator lebih besar daripada nilai Standar Deviasi, maka penyimpangan data yang terjadi rendah, sehingga penyebaran nilainya merata.

Dan 200 sampel variabel minat berinvestasi, diperoleh nilai mean masing-masing indikator lebih besar daripada nilai Standar Deviasi, maka penyimpangan data yang terjadi rendah, sehingga penyebaran nilainya merata. 
Analisis Inner Model

Tabel 2 Inner Model Analysis

\begin{tabular}{|l|c|l|l|l|l|}
\hline \multicolumn{1}{|c|}{ Model } & $\mathbf{Q}^{\mathbf{2}}$ & $\begin{array}{c}\text { Path } \\
\text { Coefficients }\end{array}$ & t-statistics & \multicolumn{1}{|c|}{$\boldsymbol{p \text { -values }}$} & $\mathbf{f}^{\mathbf{2}}$ \\
\hline Minat Berinvestasi & 0.441 & & & & \\
Motivasi & 0.384 & 0,392 & 5,330 & 0,000 & 0,214 \\
Persepsi Risiko & 0.216 & $-0,023$ & 0,369 & 0,712 & 0,001 \\
Pengetahuan Investasi & 0,271 & 0,412 & 5,928 & 0,000 & 0,235 \\
$R^{2}$ & 0,466 & & & & \\
\hline
\end{tabular}

Sumber : Hasil Pengolahan data menggunakan SmartPLS

Berdasarkan tabel 2 di atas, dapat disimpulkan bahwa variabel Pengetahuan Investasi memiliki nilai koefisien terbesar serta memiliki arah positif dalam memprediksi Minat Berinvestasi dibandingkan variabel lainnya yaitu sebesar 0,412. Selanjutnya adalah variabel Motivasi Investasi yang memiliki nilai koefisien terbesar kedua serta berarah positif terhadap variabel Minat Berinvestasi yaitu sebesar 0,392, dan yang terakhir adalah variabel persepsi risiko yang memiliki pengaruh paling kecil yaitu sebesar 0,023 serta berpengaruh negatif terhadap Minat Berinvestasi. Persamaan yang dapat dibentuk pada Tabel 4.3 adalah sebagai berikut :

\section{INTENT $=0,412 \mathrm{IKL}+0,392 \mathrm{MOT}-0,023$ PERISK}

Merujuk pada tabel 2, dapat diketahui bahwa variabel Pengetahuan Investasi memiliki pengaruh yang kuat terhadap Minat Berinvestasi dengan besarnya nilai $\mathrm{f}^{2}$ sebesar 0,235 , dan selanjutnya variabel Motivasi Investasi memiliki pengaruh yang kuat terhadap Minat Berinvestasi dengan nilai $\mathrm{f}^{2}$ sebesar 0,214 , dan terakhir variabel Persepsi Risiko memiliki pengaruh yang lemah terhadap Minat Berinvestasi dengan nilai $\mathrm{f}^{2}$ hanya sebesar 0,001 .

Berdasarkan hasil pengujian Predictive Relevance $\left(\mathrm{Q}^{2}\right)$ pada Tabel 2 di atas, diketahui nilai Predictive Relevance masing-masing variabel bernilai lebih besar dari $0(>0)$, sehingga dapat disimpulkan bahwa hubungan konstruk dari variabel-variabel yang diteliti dianggap relevan dalam mengukur model penelitian yang sebelumnya telah dibentuk.

Berdasarkan tabel 2 di atas, diperoleh nilai $R^{2}$ sebesar 0,466 atau 46,6\%. Hal ini menunjukkan bahwa sebesar $46,6 \%$ variabel terikat minat berinvestasi, dapat dijelaskan oleh variabel bebas, yaitu motivasi, persepsi risiko dan pengetahuan investasi, sedangkan sisanya sebesar 53,4\% dipengaruhi oleh variabel bebas lainnya di luar penelitian ini. Berdasarkan hasil pengujian Koefisien Determinasi, dapat disimpulkan bahwa nilai $R$-Square pada penelitian ini tergolong lemah.

Pengujian Goodness of Fit (GoF) dihitung dengan menggunakan rumus yang terdiri dari nilai Average Variance Extracted (AVE) dan nilai Koefisien Determinasi atau $R$-Square yang dilakukan dengan cara manual sebagai berikut :

$$
\begin{gathered}
A V E=\frac{0,560+0,512+0,512+0,524}{4}=0,527 \\
R^{2}=0,466 \\
G o F=\sqrt{A V E x R^{2}} \\
\text { GoF }=\sqrt{0,527 \times 0,466} \\
\text { GoF }=0.245582
\end{gathered}
$$


Berdasarkan hasil perhitungan nilai Goodness of Fit di atas, dapat disimpulkan bahwa model yang digunakan pada penelitian ini memiliki Goodness of Fit yang kecil.

\section{Uji Hipotesis}

a. Uji Hipotesis Pertama

H1: Motivasi berpengaruh secara positif terhadap Minat Berinvestasi.

Hasil pengujian hipotesis yang telah dilakukan pada Tabel 2 di atas dapat disimpulkan bahwa variabel Motivasi terbukti berpengaruh secara positif terhadap Minat Berinvestasi. Hal ini dapat dilihat dari nilai $t$-statistics dan nilai $p$-values variabel Motivasi pada Tabel 2 di atas, di mana nilai $t$-statistics sebesar 5,330 (> 1,96) dan nilai $p$-values sebesar 0,000 $(<0,05)$. Maka dapat disimpulkan bahwa H1 tidak ditolak.

b. Uji Hipotesis Kedua

H2 : Persepsi Risiko berpengaruh secara positif terhadap Minat Berinvestasi.

Hasil pengujian hipotesis yang telah dilakukan pada Tabel 2 di atas dapat disimpulkan bahwa variabel Persepsi Risiko tidak terbukti berpengaruh secara positif terhadap Minat Berinvestasi. Hal ini dapat dilihat dari nilai $t$-statistics dan nilai $p$-values variabel Persepsi Risiko pada Tabel 2 di atas, di mana nilai $t$-statistics sebesar 0,369 (< 1,96) dan nilai $p$-values sebesar 0,712 (>0,05). Maka dapat disimpulkan bahwa $\mathrm{H} 2$ ditolak.

c. Uji Hipotesis Ketiga

H3 : Pengetahuan Investasi berpengaruh secara positif terhadap Minat Berinvestasi.

Hasil pengujian hipotesis yang telah dilakukan pada Tabel 2 di atas dapat disimpulkan bahwa variabel Pengetahuan Investasi terbukti berpengaruh secara positif terhadap Minat Berinvestasi. Hal ini dapat dilihat dari nilai $t$-statistics dan nilai $p$-values variabel Pengetahuan Investasi pada Tabel 2 di atas, di mana nilai $t$-statistics sebesar 5,928 $(>1,96)$ dan nilai $p$-values sebesar $0,000(<0,05)$. Maka dapat disimpulkan bahwa H3 tidak ditolak.

\section{DISKUSI}

Hasil analisa penelitian ini didapatkan bahwa variabel motivasi berpengaruh positif terhadap minat berinvestasi. Semakin besar motivasi seseorang untuk melakukan investasi, semakin besar minat berinvestasi seseorang. Hasil ini didukung oleh penelitian yang dilakukan oleh Palamida et al., (2015), Deshmukh dan Joseph, (2016), Saputra (2018), Saraswati dan Wirakusuma (2018), Amhalmad1 dan Irianto (2019), Wi dan Anggraeni (2020) yang juga mengatakan bahwa motivasi berpengaruh positif terhadap minat berinvestasi, serta penelitian Washington dan Regina (2015) yang mengatakan di luar variabel risk and return, motivasi berpengaruh positif terhadap minat berinvestasi.

Sedangkan variabel persepsi risiko berpengaruh negatif terhadap minat berinvestasi. Semakin besar persepsi risiko seseorang, maka minat seseorang untuk berinvestasi turut meningkat. Deshmukh dan Joseph, (2016) yang mengatakan bahwa Persepsi Risiko berpengaruh positif dan signifikan terhadap Minat Berinvestasi. Setiap individu tentu memiliki pandangan yang berbeda-beda atas risiko terhadap investasi, faktor risiko ini dapat diabaikan sehingga tidak mempengaruhi minat seseorang dalam berinvestasi.

Kemudian variabel pengetahuan investasi ditemukan memiliki pengaruh positif minat berinvestasi. Semakin baik pengetahuan investasi seseorang, semakin besar minat seseorang untuk melakukan investasi. Hasil penelitian ini didukung oleh penelitian yang dilakukan oleh Kozup et al., (2008), Wang (2011), Sivaramakrishnan et al., (2017) Nauman Sadiq dan Ased Azad Khan (2019), Akhtar dan Das (2019), Zhao (2020), D.A.T (2020), serta Sumiati et al., (2021) yang mengatakan bahwa pengetahuan investasi berpengaruh positif terhadap minat berinvestasi. 


\section{KESIMPULAN}

Hipotesis pertama diterima bahwa terdapat pengaruh positif antara motivasi terhadap minat berinvestasi di masa pandemi covid-19. Hipotesis kedua ditolak. Persepsi risiko berpengaruh negatif terhadap minat berinvestasi di masa pandemi covid-19. Pada penelitian selanjutnya variabel persepsi risiko dapat digantikan dengan variabel lainnya seperti Perceived Risk atau risiko yang dirasakan, dengan harapan dapat memberikan kontribusi yang lebih besar dalam mengukur minat berinvestasi.

Hipotesis ketiga diterima bahwa terdapat pengaruh positif dan signifikan antara pengetahuan investasi terhadap minat berinvestasi di masa pandemi covid-19. Hal ini menjelaskan bahwa pandemi bukanlah sebuah halangan bagi seseorang untuk mencari pengetahuan dalam berinvestasi. Hipotesis keempat diterima bahwa motivasi, persepsi risiko dan pengetahuan investasi secara bersama-sama berpengaruh positif terhadap minat berinvestasi di masa pandemi covid-19.

\section{DAFTAR PUSTAKA}

Ajzen, I. (1991). The theory of planned behavior. Organizational Behavior and Human Decision Processes, 50(2), 179-211. https://doi.org/https://doi.org/10.1016/07495978(91)90020-T

Akhtar, F., \& Das, N. (2019). Predictors of investment intention in Indian stock markets: Extending the theory of planned behaviour. International Journal of Bank Marketing, 37(1), 97-119. https://doi.org/10.1108/IJBM-08-2017-0167

Amhalmad1, I., \& Irianto, A. (2019). Pengaruh Pengetahuan Investasi dan Motivasi Investasi Terhadap Minat Berinvestasi Mahasiswa Pendidikan Ekonomi Fakultas Ekonomi $\begin{array}{llllll}\text { Universitas Negeri Padang. Jurnal Ecogen, } & 734 .\end{array}$ https://doi.org/10.24036/jmpe.v2i4.7851

Aritonang, L. R. (1998). Riset Pemasaran Teori \& Praktik. Tarumanagara University Publishing Unit.

D.A.T, K. (2020). The Impact of Financial Literacy on Investment Decisions: With Special Reference to Undergraduates in Western Province, Sri Lanka. Asian Journal of Contemporary Education, 4(2), 110-126. https://doi.org/10.18488/journal.137.2020.42.110.126

Deshmukh, G. K., \& Joseph, S. (2016). BEHAVIOURAL FINANCE : AN INTROSPECTION OF INVESTORS PSYCHOLOGY Institute of Management Institute of Management. Indian Journal of Commerce \& Management Studies, VII(1), 97-103.

Haugen, R. A., \& Branch, B. (1977). Fundamentals of Investing. In The Journal of Finance (Vol. 32, Issue 1). https://doi.org/10.2307/2326926

Kozup, J., Howlett, E., \& Pagano, M. (2008). The effects of summary information on consumer perceptions of mutual fund characteristics. Journal of Consumer Affairs, 42(1), 37-59. https://doi.org/10.1111/j.1745-6606.2007.00093.x

Maciejewski, G. (2011). The Meaning Of Perceived Risk In Purchasing Decisions Of The Polish Customers For citation : Maciejewski G . ( 2011 ), The meaning of perceived risk in purchasing decisions of the polish customers, Scientific Annals of the "Alexandru Ioan Cuza " Univers. Scientific Annals of the University of Iasi, LVIII(August).

Nauman Sadiq, M., \& Ased Azad Khan, R. (2019). Impact of Personality Traits on Investment Intention: The Mediating Role of Risk Behaviour and the Moderating Role of Financial Literacy. Journal of Finance \& Economics Research, 4(1), 1-18. https://doi.org/10.20547/jfer1904101

Palamida, E., Papagiannidis, S., Xanthopoulou, D., \& Stamati, T. (2015). Capital, Motives, and 
Their Link to Investment Intentions: The Moderating Role of the Financial Crisis in Greece. Journal of Small Business Management, 53, 115-144. https://doi.org/10.1111/jsbm.12186

PT. Kustodian Sentral Efek Indonesia. (2020). Kaleidoskop 2020. Ksei, 12190.

Rezeki, F. A. S., \& Pitaloka, E. (2020). Faktor-Faktor Yang Mendorong Keputusan Investasi Saham Di Masa Pandemic. Prosiding Seminar Nasional Terapan ..., 6(2), 131-138. https://proceeding.isas.or.id/index.php/sentrinov/article/view/431

Saputra, D. (2018). Pengaruh Manfaat, Modal, Motivasi, dan Edukasi Terhadap Minat Berinvestasi di Pasar Modal (Studi pada Mahasiswa Sekolah Tinggi Ilmu Ekonomi Balikpapan). Future Jurnal Manajemen Dan Akuntansi, 5(2), 178-190.

Saraswati, K. R. A., \& Wirakusuma, M. G. (2018). Pemahaman Atas Investasi Memoderasi Pengaruh Motivasi dan Risiko Investasi Pada Minat Berinvestasi. E-Jurnal Akuntansi, 24, 1584. https://doi.org/10.24843/eja.2018.v24.i02.p28

Sivaramakrishnan, S., Srivastava, M., \& Rastogi, A. (2017). Attitudinal factors, financial literacy, and stock market participation. International Journal of Bank Marketing, 35(5), 818-841. https://doi.org/10.1108/IJBM-01-2016-0012

Stephen P. Robbins, N. L. (2006). Fundamentals of Organizational Behavior, third Canadian Edition. 448. https://doi.org/10.1007/978-1-137-31243-3_1

Sumiati, A., Widyastuti, U., Takidah, E., \& Suherman. (2021). The millennials generation's intention to invest: A modified model of the theory of reasoned action. International Journal of Entrepreneurship, 25(3), 1-11.

Wang, A. (2011). The effects of investment knowledge and visual communications on comprehension of investment disclosures. Journal of Financial Services Marketing, 16(2), 125-138. https://doi.org/10.1057/fsm.2011.14

Washington, M., \& Regina, R. (2015). Students' perceived risk and investment intention: the effect of brand equity. Management \& Marketing, 10(3), 208-225. https://doi.org/10.1515/mmcks-2015-0015.Correspondence

Wi, P., \& Anggraeni, D. (2020). Faktor-Faktor Yang Mempengaruhi Minat Karyawan Perusahaan Untuk Berinvestasi Di Pasar Modal Pada Masa. Revenue, 01(01), 81-89.

Widoatmodjo, S. (2009). Pasar Modal Indonesia Pengantar \& Studi Kasus, Cetakan Pertama. Ghalia Indonesia.

Zhao, H. (2020). Financial literacy or investment experience: which is more influential in cryptocurrency investment? investment. International Journal of Bank Marketing, 21. https://doi.org/10.1108/IJBM-11-2020-0552 